\title{
USING MCDA AND GIS FOR LANDFILL SITE SELECTION: CENTRAL DISTRICTS OF ANTALYA PROVINCE
}

\author{
E. Aksoy ${ }^{a}$ and B. T. San ${ }^{b, c} *$ \\ a Akdeniz University, Vocational School of Tech. Sci., Dumlupinar Blv., 07058, Antalya - Turkey, ercumentaksoy@akdeniz.edu.tr \\ ${ }^{\mathrm{b}}$ Akdeniz University, Dept. of Geological Engineering, Dumlupinar Blv., 07058, Antalya - Turkey, tanersan@akdeniz.edu.tr \\ ${ }^{\mathrm{c}}$ Akdeniz University, Remote Sensing Research and Application Center, 07058, Antalya, Turkey
}

Commission II, WG II/3

KEY WORDS: Landfill site selection, Antalya, Multi Criteria Decision Analysis, AHP, GIS

\begin{abstract}
:
The aim of this study is to select new landfill sites in Antalya, Turkey which is the fifth biggest city according to the population, approximately 1.2 million. It is the first rank according to the population growth rate in Turkey. The city of Antalya is the touristic places and its climate is Mediterranean climate. Therefore, choosing landfill site is very crucial and it affects the future of the city. Existing landfill site will not be sufficient in near future. The study was implemented in the Aksu, Dosemealti, Kepez, Konyaalti, and Muratpasa districts in Antalya. The study area has almost $1980 \mathrm{~km}$-square. Twelve parameters which are geology, fault lines, landslides, river, lake, elevation, slope, aspect, population, rain, road network, and temperature data were determined. These parameters were assessed using Analytical Hierarchy Process (AHP) method and the weights of criteria layers were computed. Then, the computed weights were checked by the consistency index and consistency ratio which were found as 0.12 and $8.5 \%$, respectively. The consistency index for 12 parameters should be lower than 1.48 and the consistency ratio should be less than $10 \%$. This means that the constructed AHP matrix is suitable for analysis. Finally, the most suitable areas for landfill were computed according to the weights achieved from AHP matrix. The results were obtained in a range between 0.39 and 0.90 . When the obtained results were compared with the existing landfill site called Kizilli area, the AHP score was found as 0.62. Therefore, new landfill area(s) should be selected from the determined results.
\end{abstract}

\section{INTRODUCTION}

Urbanization and industrialization bring lots of health problems in many big cities due to the population growth. In order to decrease these types of problems, healthy environment should be established by the local government or municipality. The leading actor of the pollution is solid wastes. The solid waste disposal is the method that reduce or diminish the pollution caused by waste. In order to dispose the waste, selection of the landfill is important.

According to the Turkish Statistical Institute (TUIK, 2014), the population of Antalya is 2,222,562 and it is the fifth biggest city in Turkey. In addition to that it is the first rank according to the population growth rate which is 2.16. As well as the local population growth i.e. migration from other cities, population increase due to tourism activities especially in May to September (almost half of the year). Therefore, the huge and growing amount of population brings about waste problem.

Antalya Province (Centre of Antalya) has already existing landfill area which is called Kizilli. However, it is required to build new landfill site because of the population increment.

Land fill site selection process contains multi-parameters which are land use, land cover, geology, water resources, roads, and population etc. The more the input parameters, the more complex to operate site selection (Sadek et. al., 2006).
In literature there are lots of studies used multi-criteria decision analysis with Geographical Information Systems (GIS) to solve different type of problems such as location of fire stations (Erden and Coskun, 2010), landslide susceptibility mapping ((Akgun and Bulut, 2007; Reis et al., 2012; Porghasemi et al., 2012; San, 2014), site selection of landfill or soil waste (Siddiqui et al., 1996; Yesilnacar et al., 2012; Guiqin et al., 2009; Nazari et al., 2012; Gorsevski et al., 2012; Vasiljevic et al., 2012; Sener et al., 2011; Pandey et al., 2012), astronomical observatory site selection (Koc-San et. Al., 2013), possible areas for nuclear waste (Carver, 1991), land-use suitability assessment (Joerin et al., 2001), locating sustainable urban centers (AbuSada and Thawaba, 2011), locations of fire stations (Erden and Coskun, 2010) and urban development (Youssef et al., 2011; Drobne and Lisec, 2009).

In addition to that Analytical Hierarchical Process (AHP) is one of the well-known techniques for multi-criteria decision analysis (MCDA). This technique was integrated with the GIS for getting more reliable and accurate results or decisions. AHP was established by Saaty (1980) to solve the complex decisions problem using pairwise comparison matrix. After his invention, Rao et. al. (1991) and Siddiqui et. al. (1996) were the first attempt to use AHP with GIS.

The aim of this study is to select new landfill sites in Antalya, Turkey. In order to perform optimum site selection, multicriteria decision analysis (AHP) used with geographical information systems.

* Corresponding author 


\section{STUDY AREA AND DATA PREPARATION}

Antalya is located in the south-south-west of the Turkey. The study area is in Antalya City and the central part of the city covering the five main districts which are Aksu, Dosemealti, Kepez, Konyaalti, and Muratpasa (Figure 1). This area which has almost $1980 \mathrm{~km}$-square area are surrounded by the Toros Mountains and Mediterranean Sea. The climate of the study area is Mediterranean climate which is dry and hot in summer and rainy and warm in winter.

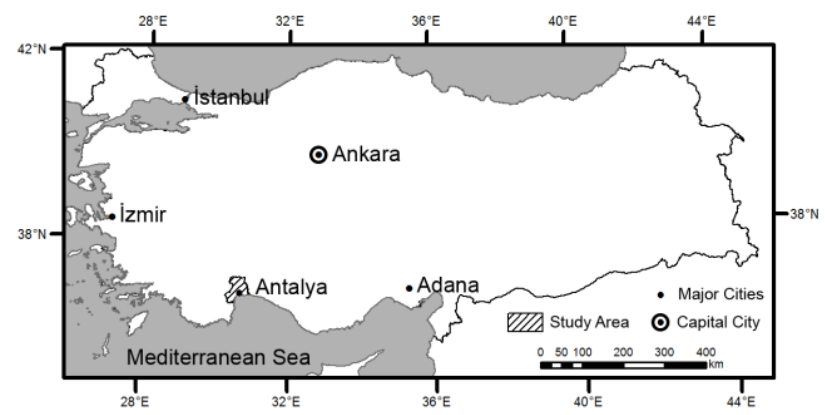

Figure 1. Study area

In this study, 12 parameters were used as input data which are geology, fault lines, landslides, river, lake, elevation, slope, aspect, earthquake zones, population, rain, road network, and temperature (Table 1).

\begin{tabular}{|c|c|c|c|}
\hline & Data Sets & & a Types \\
\hline 1 & Geology & \multirow{9}{*}{ 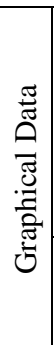 } & \multirow{6}{*}{ Vector } \\
\hline 2 & Landslide & & \\
\hline 3 & Fault Lines & & \\
\hline 4 & River & & \\
\hline 5 & Road & & \\
\hline 6 & Lake & & \\
\hline 7 & Aspect & & \multirow{3}{*}{ Raster } \\
\hline 8 & Slope & & \\
\hline 9 & DEM & & \\
\hline 10 & Population & \multirow{3}{*}{$\begin{array}{l}\frac{0}{0} \\
\frac{\pi}{\sigma}\end{array}$} & \multirow{3}{*}{ Attribute } \\
\hline 11 & Temperature & & \\
\hline 12 & Rain & & \\
\hline
\end{tabular}

Table 1. Parameters used in the study

\subsection{Geology}

Geology is the one of the main parameter that controls the site selection of landfill. Study area contains 18 different lithologies that are alluvial deposits, spilitic basalt, pebble, chert, chertylimestone, clayey limestone, mudstone, sandstone, limestone, sand dune, melange, olistostrome, peridotite, shale, travertine, volcanoclastics, and talus. Different types of lithologies have different permeability. Permeability is crucial for leakage of wastes. Therefore, lithologies were grouped into five categories according to permeability. The lowest and the highest permeability values were assigned as 1 and 0 , respectively. Figure 2 is shown the five categorized geological units according to their permeability.

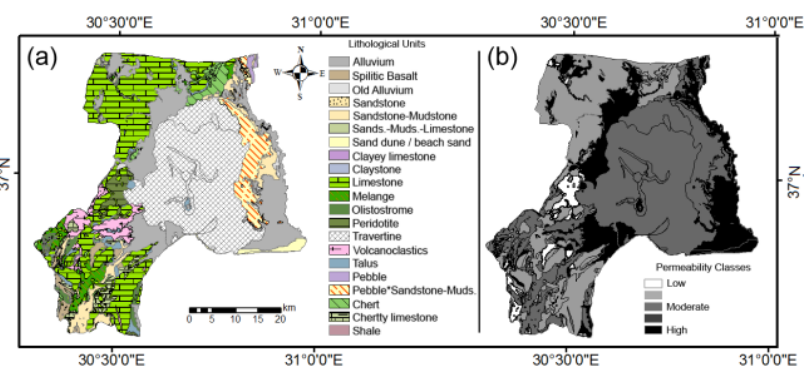

Figure 2. Classified lithological units according to permeability

\subsection{Landslide}

Landslide inventory data were digitized from General Directorate of Mineral Research and Exploration (MTATurkey). Landslides were categorized into 4 classes which are based on the Varnes (1978) classification. According to this data, landslides classifies as fall, slide and flows. Most of the landslides were located on the western part of the Antalya city centre. Even though these landslide bodies are not directly fall into the study area boundary, they are very close to the study area boundary. Therefore, distance map were generated for landslide polygons. In this map, each pixel shows the distance from the landslide polygons (Figure 3). According to obtained data, the maximum distance from the landslide is computed as $33447.1 \mathrm{~m}$. After generating the distance map, data were rescaled between 0 and 1 . If the values are close to 1 , then this area has far distance to landslide polygon(s).

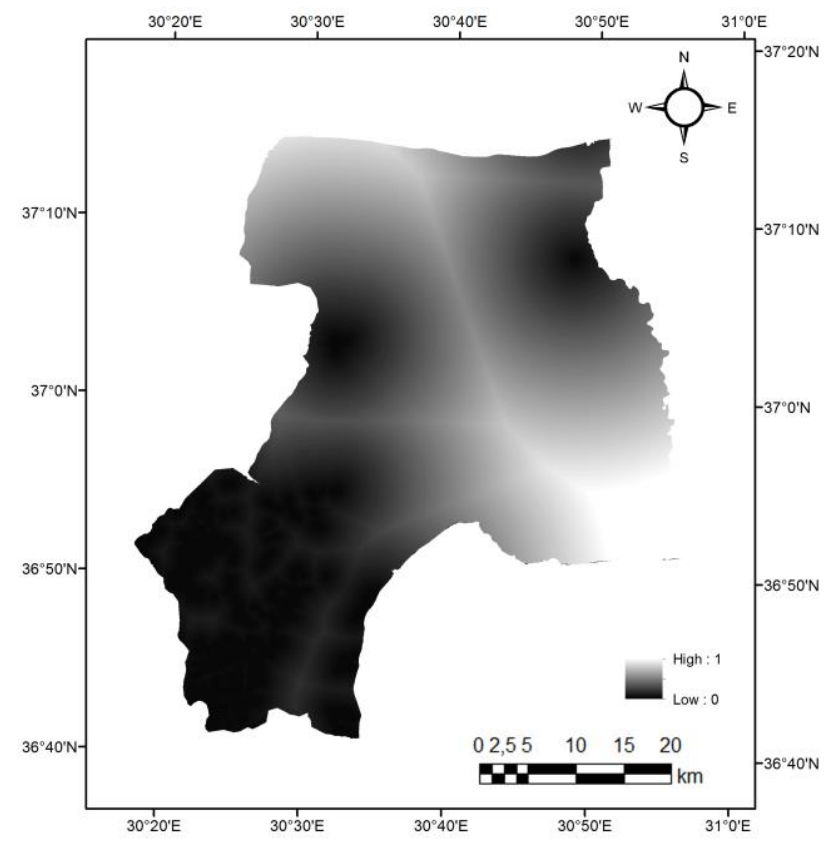

Figure 3. Distance to landslide polygons

\subsection{Fault Lines}

The fault lines were used for representing the unstable and leakage areas. During the study, distances to fault lines were generated as another parameter (Figure 5). Fault lines data is digitized from the 1:100,000-scaled geological maps of MTA. According to fault distance map, maximum distance was observed as $20975.6 \mathrm{~m}$ from the fault lines. 


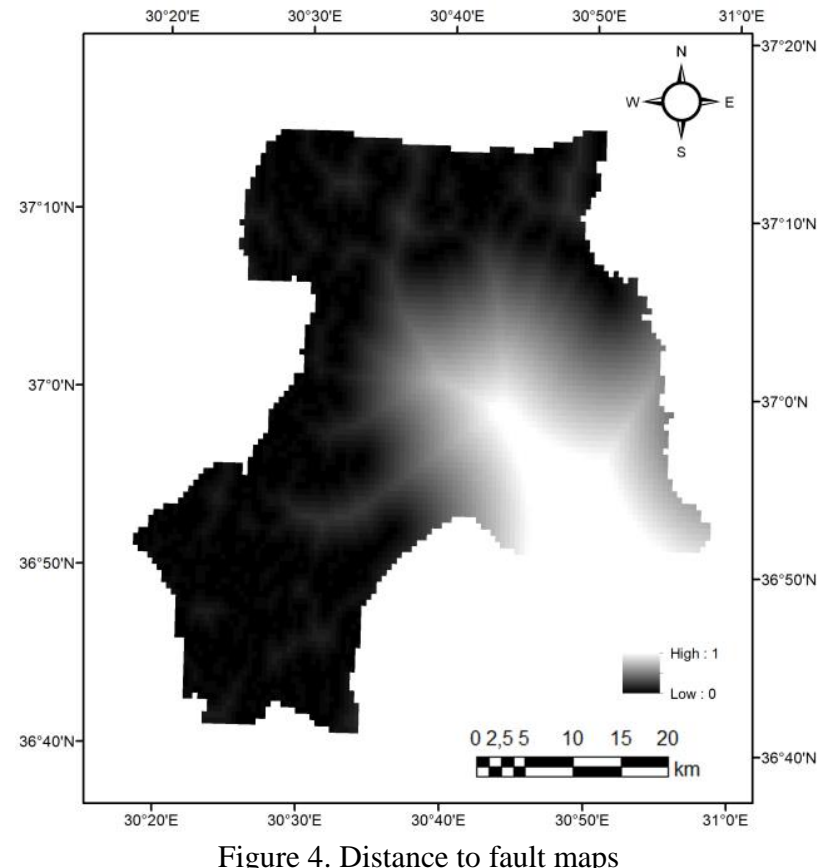

\subsection{River Networks, Lakes and Dam Reservoirs}

Antalya city one of the rich city that has its own water resources. Therefore this parameter is very important for landfill site selection. It should a distance to water resources such as river, lake and dam reservoir areas for protecting of them. The two distance maps were generated for river parameters, and lake and reservoir parameters in Figure 5 and 6.

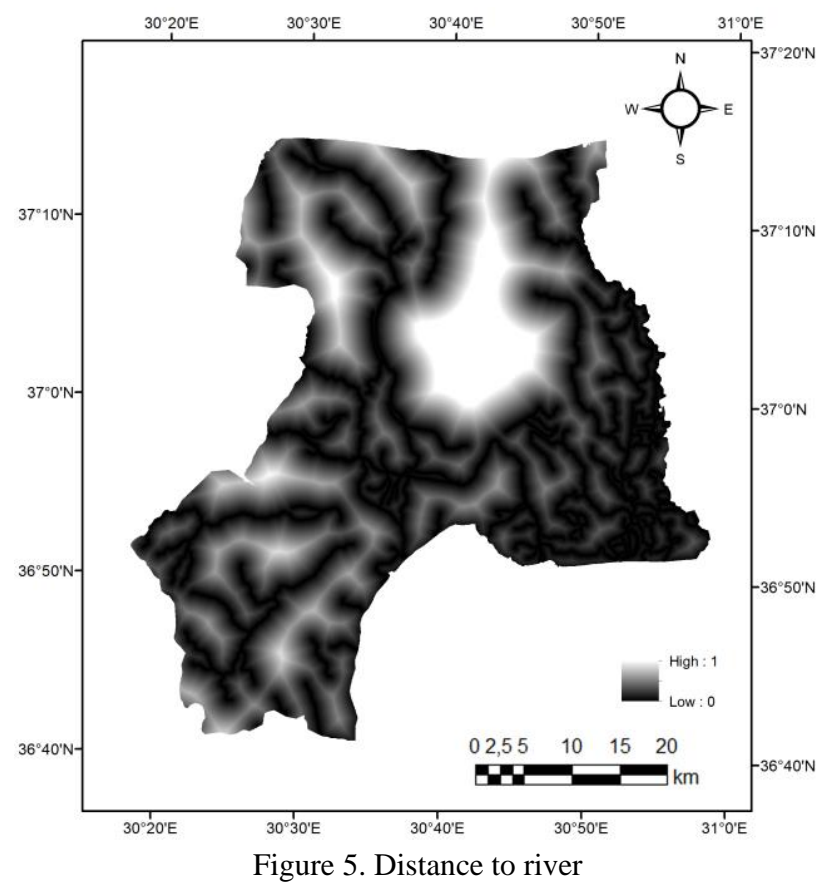

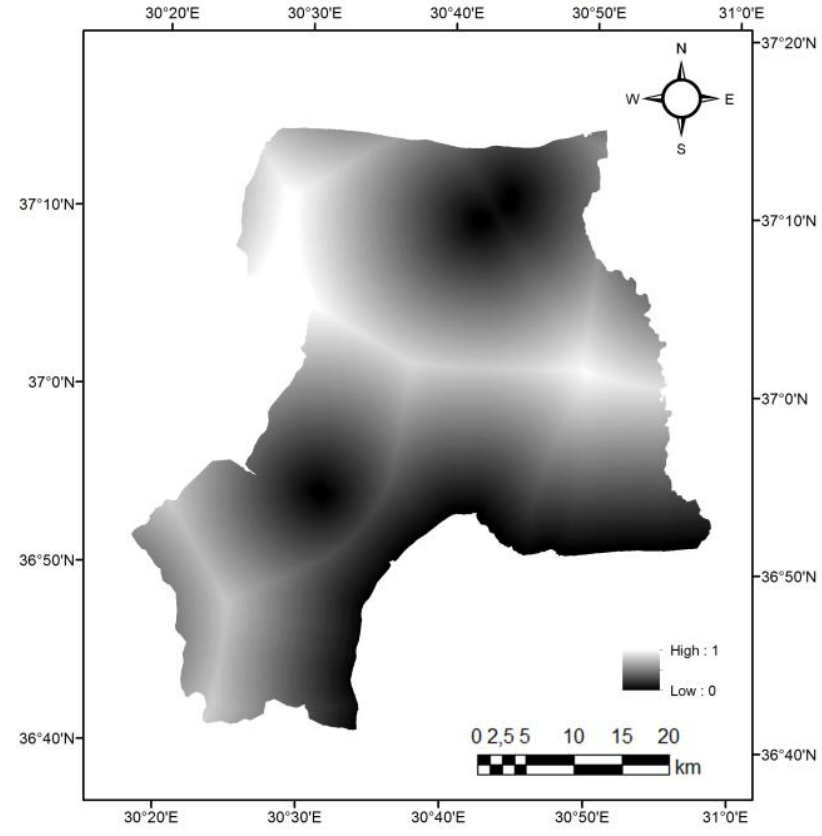

Figure 6. Distance to lake and reservoir area

\subsection{Road Networks}

Road data is used to compute distance map for site selection. In this study, highways, motorways were used as a key parameter for distance computation. The road distance data is used for the information of distance between landfill area and roads. The selected landfill area should not be close to roads. It should have a distance. Figure 7 shows the road distance. The minimum and the maximum distances are 0 and $7487.33 \mathrm{~m}$, respectively.

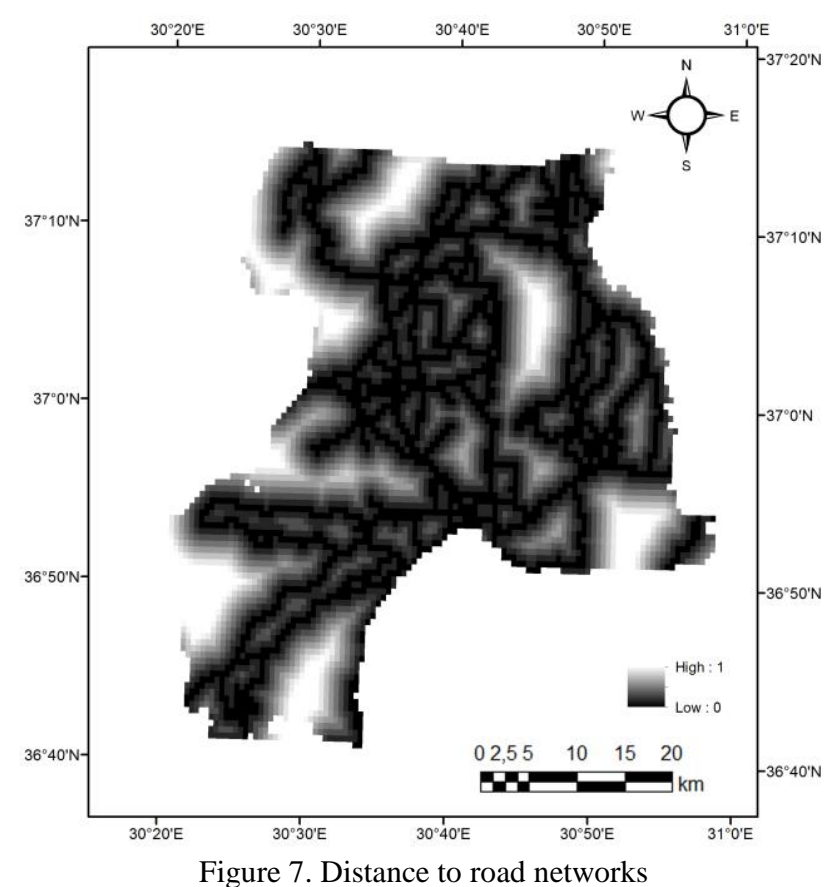

\subsection{DEM, Slope and Aspect}

In this study Digital Elevation Model (DEM) data were used from the ASTER GDEM (The Advanced Spaceborne Thermal 
Emission and Reflection Radiometer - Global Digital Elevation Model) data which has originally $30 \mathrm{~m}$ pixel size. The acquisition date of the images is $18 / 11 / 2015$. The elevation variations of study area are between 0.0 and $2617.08 \mathrm{~m}$ (Figure 8)

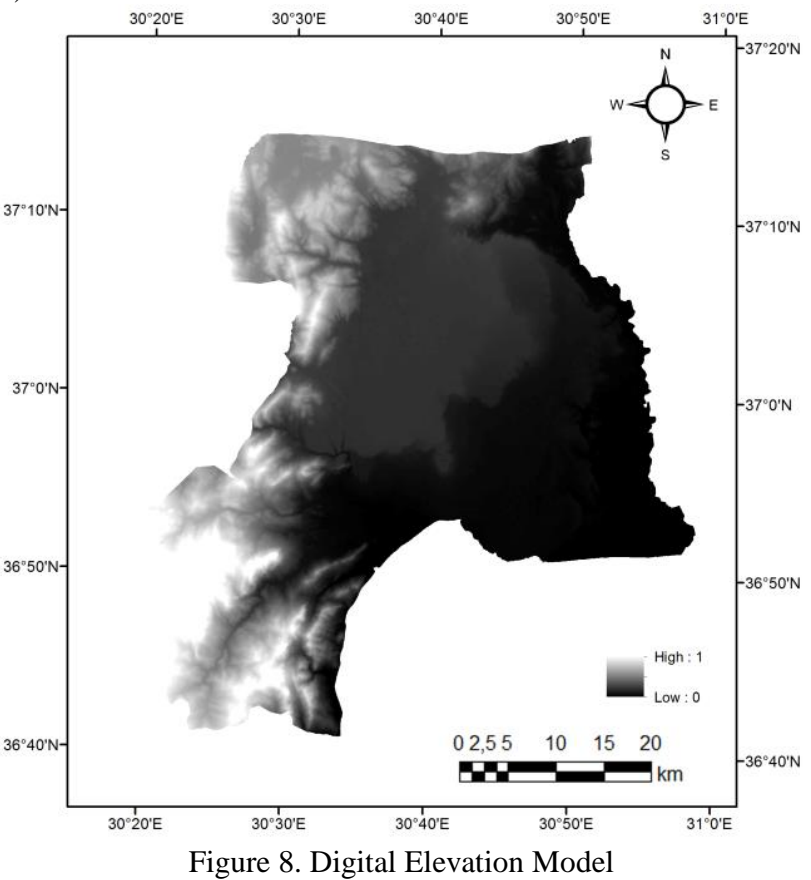

Slope which is the one of the DEM derivatives is another parameter for landfill site selection process. High slope angles are not preferable for landfill. Slope values were computed using D8 algorithm. Study area has maximum 74.9201 degree slope (Figure 9).

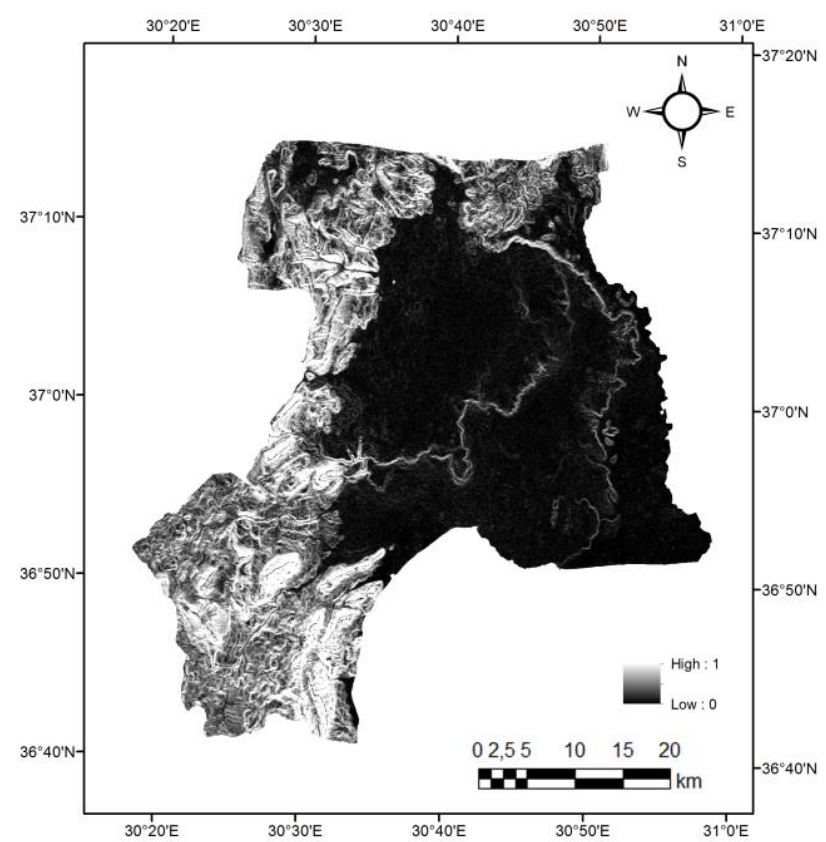

Figure 9. Slope degree of the Study area

Aspect is the direction of the slope from the azimuth. This is related with the exposure to sun that means if the slope towards to southern direction, then landfill area directly exposed to sun and decay of the wastes caused bad smelling. On the contrary, northern slopes should be more preferred for the landfill areas.
In this study, NE, N, NW slope directions and flat areas were assigned as higher scores. SE, S, and SW directions were assigned as lower scores. East and West directions were assigned as moderate scores. Figure 10 shows the aspect data of the study area.

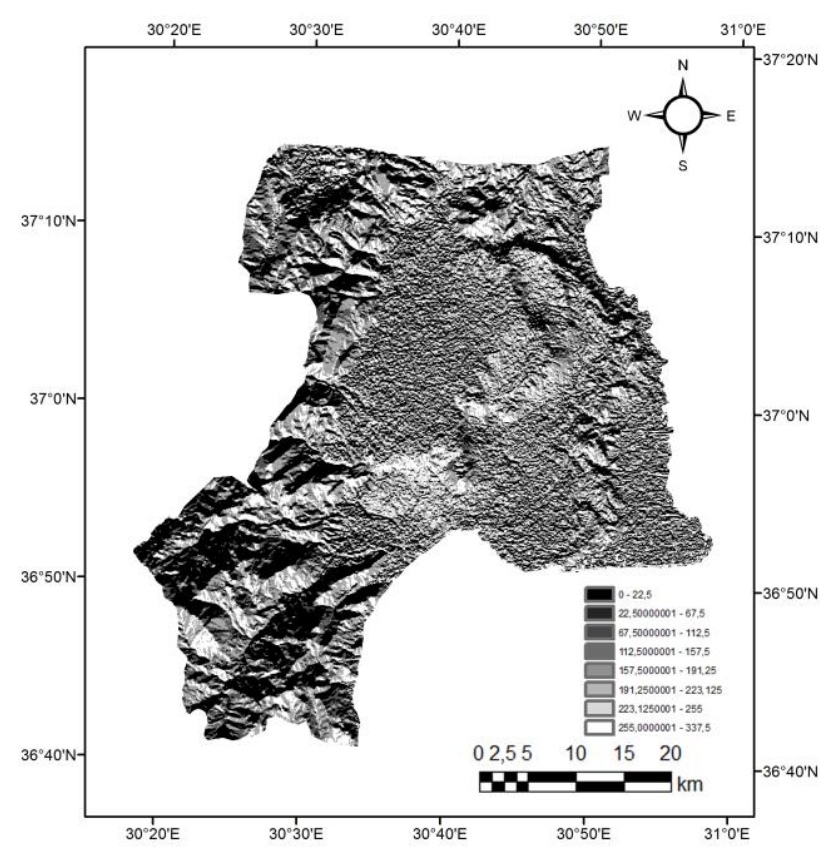

Figure 10. Aspect of the Study area

\subsection{Population Density}

Population of the study area is 1,203,984 (TUIK, 2014) and it is another parameter for landfill site selection. This parameter is also directly affected from the selected site(s). In order to use population data in the study, the latest population values were collected from the TUIK (2014) which is the Turkish Statistical Institute. There are some problems to deal with population data. For example some of the settlement areas were merged and their names were changed.

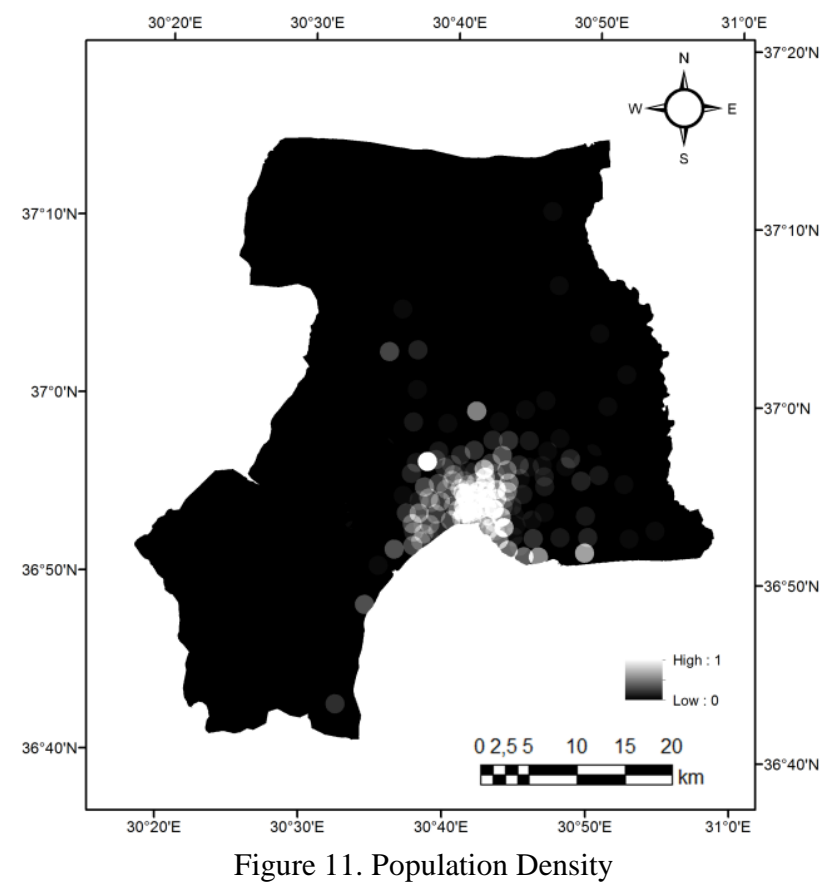


First of all, all these type of problems were solved by detailed investigations, and then all settlement centres were added to the GIS environment. Finally, population density for a km-square was computed (Figure 11). According to obtained results, maximum value is 153927 . The obtained data were also scaled between 0 and 1 .

\subsection{Temperature and Rain Data}

During the study, 5 years temperature and rain data from the 11 meteorological stations were collected to obtain the temperature and rain values of the study area. After that the kriging interpolation were used for creating spatial distribution of temperature and rain.

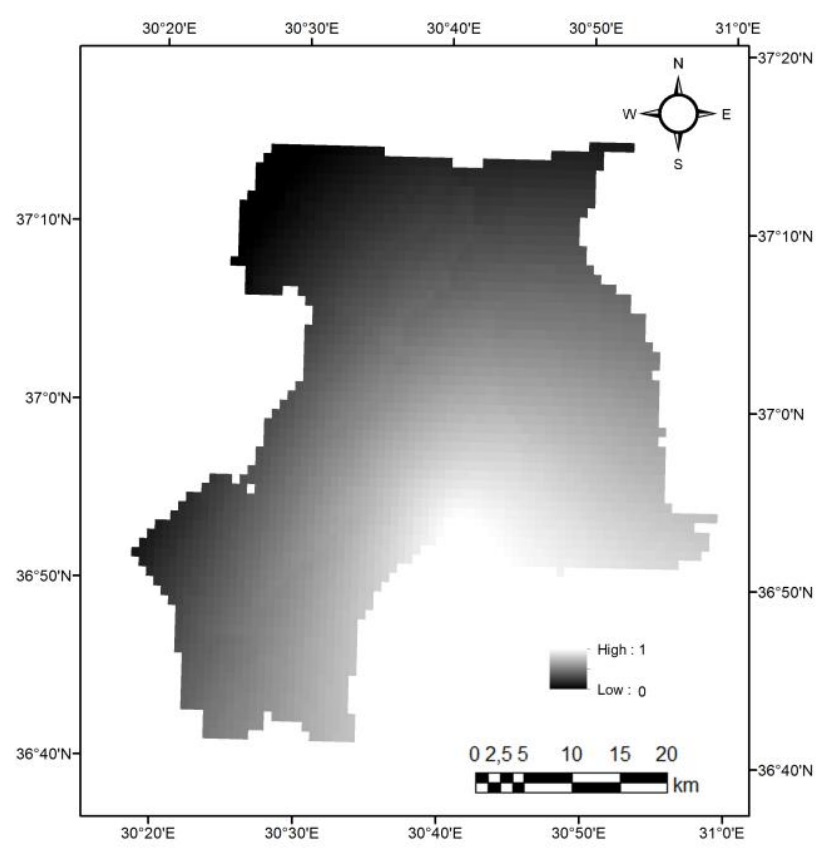

Figure 12. Temperature

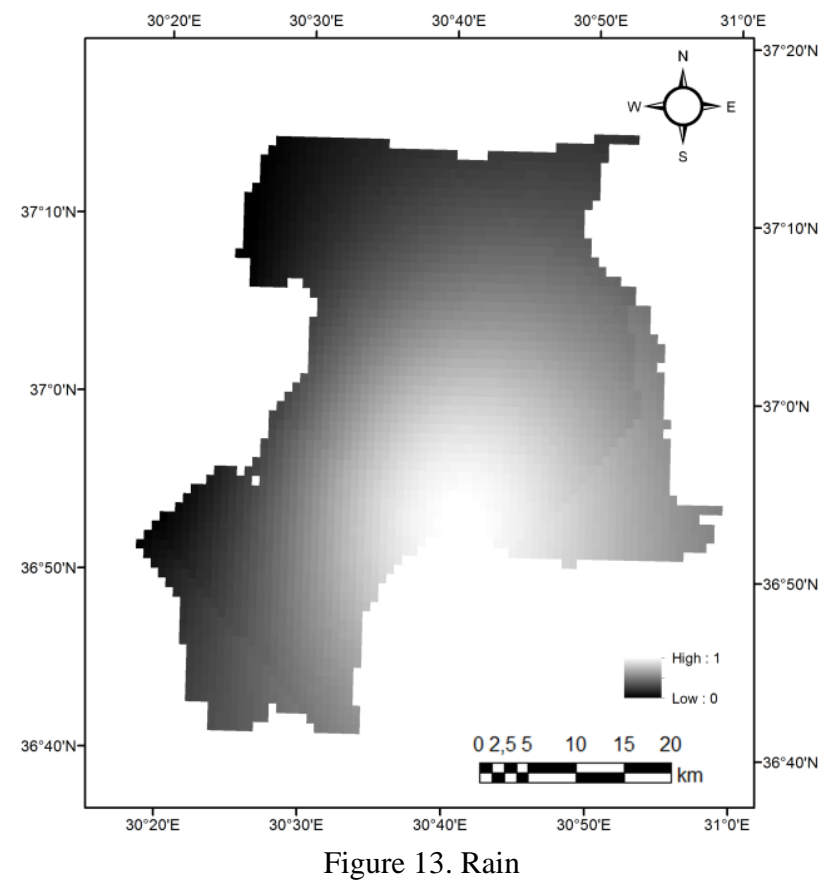

\section{METHODOLOGY}

In this study, Analytical Hierarchy Process (AHP) was used as a method for landfill site selection with multi criteria decision. All data sources were converted as raster data having $30 \mathrm{~m}$ spatial resolution by different processes such as generated distance map, density map and interpolation (i.e. kriging). These processes are called as pre-processes. At the end of these processes, each of the parameters has different scales. In order to rescale all the data sets, minimum and maximum values were computed and linearly scaled into a range between 0 and 1 which stands for the unsuitable locations and suitable locations for landfill, respectively.

In addition to rescaling operations, some of the parameters were inversed due to the consistency of the whole data sets. For example, distance maps shows high values for long distances and this is consistent for the landfill site selection idea. On the contrary, high population density values approaches to 1 . This is not consistence to landfill site selection logic. Therefore, inverse of the population density were used as input. Similarly, temperature, rain, slope, and elevation (DEM) were converted as inverse form to get consistency of the landfill site selection logic and the other parameters. If the parameter value approaches to " 1 ", then the place is suitable. On the contrary, if the parameter value approaches to " 0 ", then this location is not suitable for landfill.

Table 1 show the constructed AHP matrix which is based on pairwise comparison of the input parameters (Saaty, 1980 and Saaty, 2008). This technique is used for answer complicated problems (Cheng et. al., 1999). Each parameter compared using a matrix that contains number from 1 to 9.1 means that two of the parameter has equal effect or weight for the problem. 9 means that one of the parameter has very effected comparing the other parameter (Saaty, 1980, Saaty, 2008 and Koc-San, 2013).

\begin{tabular}{|c|c|c|c|c|c|c|c|c|c|c|c|c|c|}
\hline & A & B & C & D & E & F & G & $\mathbf{H}$ & I & $\mathbf{J}$ & K & L & w \\
\hline A & 1 & 1 & $1 / 2$ & $1 / 5$ & $1 / 6$ & $1 / 7$ & $1 / 9$ & $1 / 9$ & $1 / 9$ & $1 / 9$ & $1 / 9$ & $1 / 9$ & 0.012 \\
\hline B & 1 & 1 & $1 / 2$ & $1 / 4$ & $1 / 4$ & $1 / 4$ & $1 / 5$ & $1 / 9$ & $1 / 9$ & $1 / 8$ & $1 / 9$ & $1 / 9$ & 0.013 \\
\hline C & 2 & 2 & 1 & $1 / 4$ & $1 / 4$ & $1 / 5$ & $1 / 5$ & $1 / 8$ & $1 / 9$ & $1 / 9$ & $1 / 9$ & $1 / 9$ & 0.016 \\
\hline D & 5 & 4 & 4 & 1 & 1 & $1 / 2$ & $1 / 5$ & $1 / 6$ & $1 / 7$ & $1 / 8$ & $1 / 8$ & $1 / 8$ & \\
\hline E & 6 & 4 & 4 & 1 & 1 & $1 / 2$ & $1 / 4$ & $1 / 4$ & $1 / 5$ & $1 / 6$ & $1 / 7$ & $1 / 7$ & 0.035 \\
\hline F & 7 & 4 & 5 & 2 & 2 & 1 & $1 / 3$ & $1 / 4$ & $1 / 4$ & $1 / 5$ & $1 / 6$ & $1 / 6$ & \\
\hline G & 8 & 5 & 5 & 5 & 4 & 3 & 1 & $1 / 2$ & $1 / 3$ & $1 / 2$ & $1 / 5$ & $1 / 5$ & 0.073 \\
\hline $\mathbf{H}$ & 9 & 9 & 8 & 6 & 4 & 4 & 2 & 1 & 1 & $1 / 2$ & $1 / 3$ & $1 / 4$ & 06 \\
\hline I & 9 & 9 & 9 & 7 & 5 & 4 & 3 & 1 & 1 & 1 & 1 & $1 / 2$ & 0.138 \\
\hline $\mathbf{J}$ & 9 & 8 & 9 & 8 & 6 & 5 & 2 & 2 & 1 & 1 & 1 & 1 & .154 \\
\hline K & 9 & 9 & 9 & 8 & 7 & 6 & 5 & 3 & 1 & 1 & 1 & 1 & 0.180 \\
\hline L & 9 & 9 & 9 & 8 & 7 & 6 & 5 & 4 & 2 & 1 & 1 & 1 & o. 198 \\
\hline
\end{tabular}

Table 1. AHP matrix (A: temperature, B: aspect, C: distance to road, D: rain, E: population density, F: slope, G: DEM, H: distance to lake, I: Distance to river, J: distance to landslide, K: distance to faults, L: lithology

After adding scores into a AHP matrix, weights of the each parameters were computed as seen on Table 1 . In order to check these weighs are suitable, consistency index (CI) and consistency ratio $(\mathrm{CR})$ were computed. $\mathrm{CI}$ and $\mathrm{CR}$ values were computes as 0.127 and 0.085 , respectively. CR value is lower than $10 \%(0.10)$. This indicates that constructed AHP matrix was proper to use. Then, according to the obtained weight values, the highest and the lowest weights were 0.198 and 0.012 , respectively. 


\section{RESULTS AND DISCUSSION}

Centre of Antalya requires a new landfill site due to high population growth. In this study, 12 data sets were processed to use as input parameters for landfill site selection using multi criteria decision analysis with GIS environment.

All the parameters having the maximum values of 1 were multiplied by the weights computed from the AHP matrix. Then the following figure (Figure 14) shows the resultant map from the GIS environment with the contribution of AHP. According to the resultant map, reddish colour shows the suitable places for landfill candidate sites. The resultant map has values between 0.39 and 0.90 . The existing landfill site named Kizilli area has a value of 0.62 .

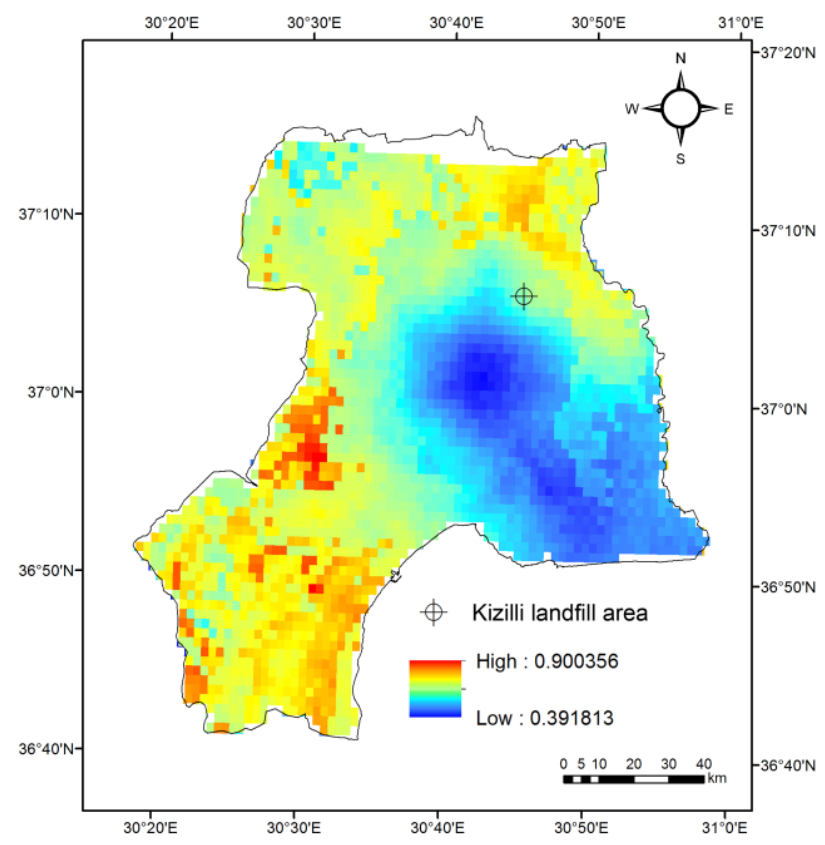

Figure 14. Suitable locations of landfill area

This resultant data depend on the input parameters and their qualities. If one of the input parameters change, then the result changes. Most of the data sets are geographical, physical and environmental and meteorological data sets i.e. fault, geology, landslide, river, lake, elevation, slope, aspect, temperature and rain. These parameters are not controlled totally. This means that these cannot be changed for the purpose of site selection. On the contrary, population and the road networks can change or can be changed. These two of them are related together. However, road network can be controlled by some restrictions such as urban planning.

Another issue is meteorological data sets which are temperature and rain data. These data were mainly obtained from the State Meteorological Institute. Data obtained from here has only past 5 years period. If the data time range increased, then the result should contain more accurate meteorological data. Another key issue is the interpreting the meteorological data which has single point measurements. However, if the spatial distribution of the meteorological data is available i.e. satellite data, then obtained results will be improved.

In this study, only input data were used to site selection. Other parameters were not taken into account such as existing laws and some protection areas for environment or resources. Therefore, an obtained result directly shows the solution for decision makers.

\section{CONCLUSION}

This study is one of the examples of landfill site selection using multi criteria decision analysis with GIS. AHP is simple and efficient to solve this type of problems. It is applied to centre of Antalya, Turkey. This approach can be expanded to whole Antalya city for each districts.

For better site selection for the future, population growth should be studied more detailed and the expansion of the city should be analyzed.

\section{REFERENCES}

AbuSada, J., Thawaba, S. 2011. Multi criteria analysis for locating sustainable suburban centers: a case study from Ramallah Governorate. Palestine. Cities 28, pp. 381-393.

Akgun, A., Bulut, F. 2007. GIS-based landslide susceptibility for Arsin-Yomra (Trabzon, North Turkey) region. Environ. Geol. 51, pp. 1377-1387.

Carver, S.J. 1991. Integrating multi-criteria evaluation with geographical information systems. Int. J. Geog. Inf. Syst. 5 (3), pp. 321-339.

Cheng, C.H., Yang, K.L., Hwang, C.L. 1999. Evaluating attack helicopters by AHP based on linguistic variable weight. Eur. J. Oper. Res. 116, 423-435.

Erden, T., Coskun, M.Z. 2010. Multi-criteria site selection for fire services: the interaction with analytic hierarchy process and geographic information systems. Nat. Hazards Earth Syst. Sci. 10, pp. 2127-2134.

Gorsevski, P.V., Donevska, K.D., Mitrovski, C.D., Frizado, J.P. 2012. Integrating multi-criteria evaluation techniques with geographic information systems for landfill site selection: a case study using ordered weighted average. Waste Manage. (Oxford) 32, pp. 287-296.

Guiqin, W., Li, Q., Guoxue, L., Lijun, C. 2009. Landfill site selection using spatial information technologies and AHP: a case study in Beijing. China. J. Environ. Manage. 90, pp. 2414-2421.

Joerin, F., Theriault, M., Musy, A. 2001. Using GIS and outranking multicriteriaanalysis for land-use suitability assessment. Int. J. Geog. Inf. Sci.15 (2), pp. 153-174.

Koç-San D., San B.T., Bakis V., Eker Z., Helvaci M., 2013. Multi-Criteria Decision Analysis Integrated With Gis And Remote Sensing For Astronomical Observatory Site Selection In Antalya Province, Turkey", Advances in Space Research, vol.52(1), pp. 39-51.

Nazari, A., Salarirad, M.M., Bazzazi, 2012. A.A. Landfill site selection by decision-making tools based on fuzzy multiattribute decision-making method. Environ. Earth Sci. 65, pp. $1631-1642$. 
Ozmen, B., Nurlu, M., Guler, H. 1997. Earthquake zones of Turkey [in Turkish], T.C. Basbakanlik Afet ve Acil Durum Yonetimi Baskanligi Deprem Dairesi Baskanligi, Ankara, Turkey.

Pandey, P.C., Sharma, L.K., Nathawat, M.S. 2012. Geospatial strategy for sustainable management of municipal solid waste for growing urban environment. Environ. Monit. Assess. 184, pp. 2419-2431.

Porghasemi, H.R., Pradhan, B., Gokceoglu, C., Moezzi, K.D. 2012. Landslide susceptibility mapping using a spatial multi criteria evaluation model at Haraz Watershed, Iran, in: Pradhan, B., Buchroither, M. (Eds.), Terrigenous Mass Movements. Springer-Verlag, Berlin Heidelberg, pp. 23-49, Chapter 2, ISBN:978-3-642-25494-9.

Rao, M., Sastry, S.V.C., Yadar, P.D., Kharod, K., Pathan, S.K., Dhinwa, P.S., Majumdar, K.L., Kumar, D.S. 1991. A weighted index model for urban suitability assessment - a GIS approach case study for Bombay Metropolitan Regional Development Authority, Bombay. Project report SAC/RSA/NRIS-URIS/TN03/February, Space Applications Centre and Bombay Metropolitan Region Development Authority.

Reis, S., Yalcin, A., Atasoy, M., Nisanci, R., Bayrak, T., Erduran, M., Sancar, C., Ekercin, S. 2012. Remote sensing and GIS-based landslide susceptibility mapping using frequency ratio and analytical hierarchy methods in Rize province (NE Turkey). Environ. Earth Sci. 66, pp. 2063- 2073.

Saaty, T.L. 1980. The Analytic Hierarchy Process. McGrawHill, New York, pp. 287.

Saaty, T.L. 2008. Relative measurement and its generalization in decision making why pairwise comparisons are central in mathematics for the measurement of intangible factors the analytic hierarchy/network process. Rev. R. Acad. Cien. Serie A. Mat. (RACSAM). Stat. Oper. Res. Survey 102 (2), 251-318.

Saaty, T.L. The Analytic Hierarchy Process. McGraw-Hill, New York, pp. 287, 1980.

Sadek, S., El-Fadel, M. ve Feiha, F. 2006. Compliance factors within a GIS based frame work for landfill siting, International Journal of Environmental Studies, 63 (1), pp. 71-86

San B.T. 2014. An Evaluation of SVM Using Polygon-Based Random Sampling in Landslide Susceptibility Mapping: The Candir Catchment Area (Western Antalya, Turkey), International Journal of Applied Earth Observation and Geoinformation, 26(1), pp. 399-412.

Sener, S., Sener, E., Karaguzel, R. 2011. Solid waste disposal site selection with GIS and AHP methodology: a case study in Senirkent-Uluborlu (Isparta) Basin. Turkey. Environ. Monit. Assess. 173, pp. 533-554.

Siddiqui, M.Z., Everett, J.W., Vieux, B.E. 1996. Landfill siting using geographic information systems: a demonstration. $J$. Environ. Eng. ASCE 122 (6), pp. 515-523.

TUIK, 2014. The Report of the population record System based on addresses (ADNKS), https://biruni.tuik.gov.tr/ adnksdagitapp/adnks.zul (01.04.2015)
Varnes, D.J., 1978. Landslides types and processes, landslides and engineering practice. In: Eckel, E.B. (Ed.), Highway Research Board Spec Report, 29. National Research Council, USA, pp. 20-47.

Vasiljevic, T.Z., Srdjevic, Z., Bajcetic, R., Miloradov, M.V. 2012. GIS and the Analytic Hierarchy Process for regional landfill site selection in transitional countries: A case study from Serbia. Environ. Manage. 49, pp. 445-458.

Yesilnacar, M.I., Suzen, M.L., Sener Kaya, B., Doyuran, V. 2012. Municipal solid waste landfill site selection for the city of Sanliurfa-Turkey: an example using MCDA integrated with GIS. Int. J. Digital Earth 5 (2), pp. 147-164.

Youssef, A.M., Pradhan, B., Tarabees, E. 2011. Integrated evaluation of urban development suitability based on remote sensing and GIS techniques: contribution from the analytic hierarchy process. Arab. J. Geosci. 4, pp. 463-473. 